\title{
Problem stosowania przepisów o pomocy publicznej do działalności kulturalnej
}

\author{
The problem of applying the State aid provisions to cultural activities \\ Проблема применения правил о государственной помощи к культурной \\ деятельности \\ MAŁGORZATA CILAK \\ Dr, Uniwersytet Mikołaja Kopernika w Toruniu \\ e-mail: mcilak@umk.pl, https://orcid.org/0000-0003-1429-8429
}

\begin{abstract}
Streszczenie: Przedmiotem artykułu jest zbadanie, czy przepisy o pomocy publicznej znajdują zastosowanie do niektórych działań mieszczących się w pojęciu "wspierania kultury i zachowania dziedzictwa kulturowego" w rozumieniu art. 107 ust. 3 lit. d Traktatu o funkcjonowaniu Unii Europejskiej. W pracy ustalono, że do działań w sferze kultury i dziedzictwa kulturowego stosuje się przepisy dotyczące pomocy publicznej, jeżeli działania dotyczą finansowania ze środków publicznych przedsiębiorstwa. Problematyczna jest jednak w niektórych przypadkach ocena, kiedy taka sytuacja ma miejsce. W artykule poddano badaniu niektóre decyzje Komisji Europejskiej, a także jej późniejsze stanowisko wyrażone w dokumencie Zawiadomienie Komisji w sprawie pojęcia pomocy państwa w rozumieniu art. 107 ust. 1 Traktatu o funkcjonowaniu Unii Europejskiej.
\end{abstract}

Słowa kluczowe: pomoc publiczna, instytucja kultury, kultura, dziedzictwo kulturowe

Summary: The aim of the article is to examine whether the provisions on State aid apply to certain activities falling within the concept of "supporting culture and preserving cultural heritage" within the meaning of Article $107(3)$ (d) of the Treaty on the Functioning of the EU. The article stated that the provisions on State aid apply to activities in the sphere of culture and cultural heritage if the activities concern financing the enterprise from public funds. However, it is problematic in some cases to judge when this is the case. The article examines some decisions of the European Commission, as well as its later position expressed in the document Commission Notice on the notion of State aid as referred to in Article 107(1) of the Treaty on the Functioning of the European Union.

Key words: State aid, cultural institution, culture, cultural heritage

Резюме: Цель статьи - рассмотреть, применяются ли правила о помощи, предоставляемой государствами, к определенным видам деятельности, подпадающим под понятие «продвижение культуры и сохранение культурного наследия» в значении статьи 107(3)(d) «Договора о функционировании Европейского Союза». Исследование показало, что правила о государственной помощи применяются к действиям в области культуры и культурного наследия, если эти действия связаны с государственным финансированием предприятия. Однако в некоторых случаях оценить, действительно ли это так, проблематично. В статье рассматриваются некоторые решения Европейской комиссии, а также ее последующая позиция, выраженная в документе: Извещение Комиссии о концепиии государственной помощи в значении статьи 107(1) Договора о функционировании Европейского Союза.

Ключевые слова: государственная помощь, учреждение культуры, культура, культурное наследие 


\section{Wstęp}

Dbanie o rozwój kultury i zachowanie dziedzictwa kulturowego stanowi jedno z ważnych zadań, które powinno wykonywać państwo. Ich realizacja odbywa się poprzez utrzymywanie publicznych instytucji kultury, dofinansowywanie inicjatyw kulturalnych podejmowanych przez podmioty prywatne, pokrywanie kosztów ochrony zabytków, stwarzanie zachęt finansowych dla produkcji kulturalnych, wydawców czy twórców.

Wykonując różne zadania związane z kulturą i dziedzictwem kulturowym, organy państwowe niejednokrotnie spotykają się z kwestią pomocy publicznej, którą stosuje się również do finansowania zadań w tych sferach.

Stosowanie przepisów o pomocy publicznej stanowi niejednokrotnie problem, ponieważ opierają się one na niezbyt precyzyjnych pojęciach, takich jak „przedsiębiorstwo”, „działalność gospodarcza” czy „wpływ na wymianę handlową między państwami członkowskimi”. Dodatkową trudnością jest odmienna interpretacja pojęć „przedsiębiorstwa” i „działalności gospodarczej” w unijnym prawie pomocy publicznej i odpowiadających im pojęć w prawie krajowym. W efekcie działanie będące realizacją zadania publicznego w świetle prawa krajowego może być ocenione jako finansowanie działalności gospodarczej w świetle prawa UE o pomocy publicznej ${ }^{1}$. Powoduje to niepewność prawną co do możliwości podjęcia działań przez państwo oraz zastosowania właściwych procedur. W obecnym stanie prawnym kwestie te wyjaśnia dokument Komisji Europejskiej (dalej: Komisja, KE): Zawiadomienie $w$ sprawie pojęcia pomocy państwa w rozumieniu art. 107 ust. 1 Traktatu o funkcjonowaniu Unii Europejskiej².

Przedmiotem opracowania jest zbadanie, w jakich przypadkach do finansowania przez państwo działalności kulturalnej oraz działalności polegającej na zachowaniu dziedzictwa kulturowego znajdują zastosowanie przepisy o pomocy publicznej. Zostanie przedstawiony problem, czy niektóre działania państwa w sferze kultury i dziedzictwa kulturowego powinny podlegać przepisom o pomocy publicznej, oraz stan prawny ukształtowany w wyniku wydania Zawiadomienia w sprawie pojęcia pomocy państwa.

1 O. Simeon, P. Staviczky, M. Könings, M. Haralampopoulou, A. Jakob, C. Pettigs, State Aid for culture: best practices at regional and local level, s. 3, http://www.issirfa.cnr.it/andrea-ciaffi-e-cecilia-odone-a-cura-di-le-politiche-europee-per-le-regioni-dalle-policies-alla-regulation-dicembre-2016.html [dostęp: 5.11.2020 r.].

2 Zawiadomienie w sprawie pojęcia pomocy państwa w rozumieniu art. 107 ust. 1 Traktatu o funkcjonowaniu Unii Europejskiej, Dz. Urz. UE C 262 z 19.07.2016, s. 1 (dalej: Zawiadomienie w sprawie pojęcia pomocy państwa; Zawiadomienie). 


\section{Pojęcie kultury i dziedzictwa kulturowego oraz zadania państwa w tych sferach}

Pojęcie kultury może mieć kilka znaczeń. Może oznaczać wychowanie czy normy zachowań wytworzone przez społeczeństwo ${ }^{3}$. Kultura znajduje odzwierciedlenie w dziełach sztuki, literatury, muzyki i tańca, zwyczajów danej społeczności itp. Jest ona źródłem tożsamości członków danej wspólnoty, kształtuje jej świadomość, przekazuje uniwersalne wartości z pokolenia na pokolenie. Podtrzymywanie i rozwijanie kultury oraz dbanie o dziedzictwo kulturowe jest zatem istotnym zadaniem leżącym w interesie publicznym.

Pojęcia kultury i dziedzictwa kulturowego nie posiadają definicji legalnych w prawie polskim. Są w nim natomiast zdefiniowane odpowiedniki terminu dziedzictwa kulturowego w postaci zabytku oraz dobra kultury ${ }^{4}$. Pojęcie „dziedzictwa kulturalnego" wydającego się być odpowiednikiem zabytku lub dobra kultury definiuje ponadto Konwencja UNESCO w sprawie ochrony światowego dziedzictwa kulturalnego i naturalnego z $1972 \mathrm{r}^{5}$

Mimo braku definicji legalnych polskie prawo posługuje się pojęciami kultury, dziedzictwa kulturowego czy działalności kulturalnej, ustanawiając zadania państwa w sferze kultury oraz przewidując finansowanie ze środków publicznych różnych przedsięwzięć kulturalnych.

Za istotny w tym kontekście należy uznać art. 6 ust. 1 Konstytucji RP ${ }^{6}$, zgodnie z którym Rzeczpospolita Polska stwarza warunki upowszechniania i równego dostępu do dóbr kultury, będącej źródłem tożsamości narodu polskiego, jego trwania i rozwoju. Zgodnie natomiast $\mathrm{z}$ art. 1 ust. 1 ustawy z dnia 25 października 1991 r. o organizowaniu i prowadzeniu działalności kulturalnej działalność ta polega na tworzeniu, upowszechnianiu i ochronie kultury. Mogą ją prowadzić

3 Zob. Kultura, w: Encyklopedia PWN, https://encyklopedia.pwn.pl/haslo/kultura;3928887.html [dostęp: 5.11.2020 r.].

$4 \quad$ Zgodnie z art. 3 pkt 1 ustawy z dnia 23 lipca 2003 r. o ochronie zabytków i opiece nad zabytkami (Dz. U. z 2021 r. poz. 710 z poźn. zm.), zabytkiem jest „nieruchomość lub rzecz ruchoma, ich części lub zespoły, będące dziełem człowieka lub związane z jego działalnością i stanowiące świadectwo minionej epoki bądź zdarzenia, których zachowanie leży w interesie społecznym ze względu na posiadaną wartość historyczną, artystyczną lub naukową". Do pojęcia zabytku odwołuje się z kolei definicja pojęcia „dobro kultury”, zob. art. 2 pkt 1 ustawy z dnia 25 maja 2017 r. o restytucji narodowych dóbr kultury, Dz. U. z 2019 r. poz. 1591.

5 Konwencja UNESCO w sprawie ochrony światowego dziedzictwa kulturalnego i naturalnego, Paryż, 16 listopada 1972 r., Dz. U. z 1976 r. Nr 32, poz. 190.

$6 \quad$ Konstytucja RP z dnia 2 kwietnia 1997 r., Dz. U. z 1997 r. Nr 78, poz. 483 z późn. zm.

7 Ustawa z dnia 25 października 1991 r. o organizowaniu i prowadzeniu działalności kulturalnej, Dz. U. z 2020 r. poz. 194 z późn. zm. 
zarówno podmioty publiczne, zwłaszcza państwowe i samorządowe instytucje kultury, jak i podmioty niepubliczne. Państwo sprawuje mecenat nad działalnością kulturalną polegający na wspieraniu i promocji twórczości, edukacji i oświaty kulturalnej, działań i inicjatyw kulturalnych, a także opieki nad zabytkami i ochrony dziedzictwa narodowego. Ustawa wskazuje na zadania i obowiązki państwa w sferze kultury, organizację i finansowanie działalności kulturalnej.

Zadania państwa w sferze kultury wynikają również z innych ustaw, np. ustawy z dnia 21 listopada 1996 r. o muzeach ${ }^{8}$, ustawy o ochronie zabytków i opiece nad zabytkami czy ustawy z dnia 27 czerwca 1997 r. o bibliotekach ${ }^{9}$. Ponadto można wskazać na szereg regulacji różnych innych ustaw skierowanych do podmiotów prowadzących działalność kulturalną, muzealną, artystyczną czy też samych artystów i twórców. Przewidują one np. poręczenia państwowe wypłaty odszkodowań za zniszczone eksponaty podczas wystaw artystycznych dla nierezydentów ${ }^{10}$, systemy ulg podatkowych oraz specjalne rozwiązania w zakresie ubezpieczeń społecznych dla artystów i twórców ${ }^{11}$, pokrywanie ze środków publicznych kosztów remontów zabytkowych obiektów oraz prowadzenia prac archeologicznych przez podmioty prywatne ${ }^{12}$, wsparcie produkcji filmowej ${ }^{13} \mathrm{i}$ inne.

Prawo Unii Europejskiej również dostrzega wagę kultury. W art. 167 Traktatu o funkcjonowaniu Unii Europejskiej ${ }^{14}$ przewidziano podstawowe zadania UE w tych sprawach. Zgodnie z tym przepisem Unia przyczynia się do rozkwitu kultur państw członkowskich w poszanowaniu ich różnorodności narodowej i regionalnej, równocześnie podkreślając znaczenie wspólnego dziedzictwa kulturowego. Działania UE zmierzają do zachęcenia do współpracy między państwami członkowskimi, a w razie potrzeby wspierania i uzupełniania ich działań. Ważną regulacją jest ust. 4 tego przepisu, zgodnie z którym Unia uwzględnia aspekty kulturalne w swoim działaniu na podstawie innych postanowień traktatów, zwłaszcza w celu poszanowania

8 Ustawa z dnia 21 listopada 1996 r. o muzeach, Dz. U. z 2020 r. poz. 902.

$9 \quad$ Ustawa z dnia 27 czerwca 1997 r. o bibliotekach, Dz. U. z 2019 r. poz. 1479.

10 Art. 23 ustawy z dnia 8 maja 1997 r. o poręczeniach i gwarancjach udzielanych przez Skarb Państwa oraz niektóre osoby prawne, Dz. U. z 2021 r. poz. 442.

11 Np. art. 120 ust. 2 i 3 ustawy z dnia 11 marca 2004 r. o podatku od towarów i usług, Dz. U. z 2021 r. poz. 685 z późn. zm.; art. 22 ust. 9 ustawy z dnia 26 lipca 1991 r. o podatku dochodowym od osób fizycznych, Dz. U. z 2021 r. poz. 1128 z późn. zm.

12 Art. 71-83b ustawy o ochronie zabytków i opiece nad zabytkami.

13 Art. 22-27 ustawy z dnia 30 czerwca 2005 r. o kinematografii, Dz. U. z 2021 r. poz. 257.

14 Traktat o funkcjonowaniu Unii Europejskiej (wersja skonsolidowana), Dz. Urz. UE nr C 202 z 7.06.2016, s. 1 (dalej: Traktat; TFUE). 
i popierania różnorodności jej kultur. Przepis ten stosuje się do oceny pomocy publicznej na wspieranie kultury i zachowanie dziedzictwa kulturowego ${ }^{15}$.

Zawiadomienie w sprawie pojęcia pomocy państwa wyjaśnia, na potrzeby stosowania przepisów o pomocy publicznej, rodzaje działań zaliczające się do sfery kultury i dziedzictwa kulturowego. W punkcie 33 wymienia m.in.: muzea, archiwa, biblioteki, ośrodki lub przestrzenie kulturalne i artystyczne, teatry, opery, sale koncertowe, obiekty archeologiczne, pomniki, obiekty i budynki historyczne, zwyczaje ludowe i rękodzieło, festiwale i wystawy, jak również edukację kulturalną i artystyczną.

\section{Pojęcie pomocy publicznej i jej dopuszczalność}

Art. 107 ust. 1 TFUE uznaje za niezgodną z rynkiem wewnętrznym pomoc pochodzącą od państwa lub przy użyciu zasobów państwowych zakłócającą lub mogącą zakłócić konkurencję poprzez sprzyjanie produkcji niektórych towarów lub branż, o ile wywiera ona wpływ na wymianę handlową między państwami członkowskimi. Beneficjentem pomocy musi być przedsiębiorstwo - podmiot prowadzący działalność gospodarczą rozumianą jako oferowanie dóbr bądź usług na danym rynku ${ }^{16}$.

Aby przekazanie mu środków publicznych stanowiło pomoc, powinien on w wyniku ich otrzymania uzyskać korzyść, której nie uzyskałby w normalnych warunkach rynkowych.

Art. 107 ust. 1 TFUE nie wyjaśnia bliżej pojęć, którymi operuje. Ich interpretacja ukształtowała się w wyniku stosowania art. 107 TFUE przez KE i Trybunał Sprawiedliwości Unii Europejskiej (dalej: TSUE). Dorobek tych instytucji w tym zakresie został podsumowany w dokumencie KE Zawiadomienie w sprawie pojęcia pomocy państwa. Środkami pochodzącymi od państwa są np. dotacje, ale również ulgi podatkowe, gwarancje i poręczenia, których koszty pokrywane są ze środków publicznych, i inne. Selektywność wyraża się ograniczeniem dostępności środka do niektórych podmiotów spośród wszystkich potencjalnie zainteresowanych. Zakłócenie konkurencji oznacza zmianę warunków rynkowych wskutek przyznania środka. Wywarcie wpływu na wymianę handlową między państwami członkowskimi

15 E. Psychogiopoulou, State Aids to the Publishing Industry and Cultural Policies in Europe, European State Aid Law Quarterly 2013, t. 12, nr 1, s. 70.

16 Pojęcie to na gruncie prawa UE jest szerokie i mieszczą się w nim podmioty, takie jak fundacje, stowarzyszenia czy instytucje kultury - bez względu na ich status w prawie krajowym. M. Stoczkiewicz, Pomoc państwa dla przedsiębiorstw energetycznych w prawie Unii Europejskiej, Warszawa 2011, s. 62-64. 
oznacza, że wpływa on na pozycję konkurentów beneficjenta, którymi są przedsiębiorstwa $z$ innych krajów członkowskich UE. Przesłanka ta jest szeroko interpretowana. Zasadniczo może wystąpić bez względu na rozmiar działalności beneficjenta czy rodzaj rynku, na którym działa (krajowy czy międzynarodowy) ${ }^{17}$.

Wskazuje się, że spośród powyższych przesłanek największe wątpliwości budzą zazwyczaj dwie kwestie: charakter działalności beneficjenta środka oraz wywarcie wpływu na wymianę handlową między państwami członkowskimi ${ }^{18}$.

W świetle art. 107 ust. 1 TFUE środek, który spełnia łącznie wszystkie przesłanki wynikające $\mathrm{z}$ tego przepisu, stanowi pomoc publiczną niezgodną z rynkiem wewnętrznym. Pomoc taka nie może być wprowadzona w życie przez państwo członkowskie. Jednak TFUE przewiduje wyjątki od tego zakazu. Wynikają one m.in. z kolejnych ustępów art. 107 (2. i 3.), a także z innych artykułów Traktatu.

Zasadniczo państwa członkowskie mają obowiązek zgłaszania wszelkich środków stanowiących pomoc publiczną Komisji, która ocenia charakter środka (czy stanowi on pomoc) oraz czy pomoc ta jest zgodna $\mathrm{z}$ rynkiem wewnętrznym (czy mieści się w którymś z wyjątków przewidzianych w Traktacie). Procedurę zgłoszeniową reguluje rozporządzenie Rady UE nr 1589/2015 ustanawiające szczegółowe zasady stosowania art. 108 TFUE $^{19}$. KE przewidziała również możliwość zastosowania tzw. procedury uproszczonej ${ }^{20}$, stosowanej w sprawach niebudzących wątpliwości prawnych oraz pozwalającej na uzyskanie decyzji KE szybciej niż w procedurze standardowej. Niektóre rodzaje pomocy są zwolnione z obowiązku zgłoszenia. Dotyczy to pomocy mniejszych rozmiarów - de minimis oraz pomocy w ramach tzw. wyłączeń blokowych (grupowych).

17 I. Postuła, A. Werner, Prawo pomocy publicznej, Warszawa 2008, s. 84-87; E. Szyszczak, Distortion of Competition and Effect on Trade between EU Member States, w: H.C.H. Hofmann, C. Micheau, State Aid Law of the European Union, Oxford 2016, s. 154-158. Bardziej szczegółowe wyjaśnienia nt. przesłanek pomocowych zawiera Zawiadomienie.

18 P. Nicolaides, Why Can the Commission not be consistent in its analysis of economic activity and affectation of trade?, https://www.lexxion.eu/stateaidpost/why-can-the-commission-not-be-consistent-in-its-analysis-of-economic-activity-and-affectation-of-trade/ [dostęp: 5.11 .2020 r.]; O. Simeon, P. Staviczky, M. Könings, M. Haralampopoulou, A. Jakob, C. Pettigs, State Aid for culture: best practices..., s. 3.

19 Rozporządzenie Rady UE nr 1589/2015 z dnia 13 lipca 2015 r. ustanawiające szczegółowe zasady stosowania art. 108 Traktatu o funkcjonowaniu Unii Europejskiej, Dz. Urz. UE nr L 248 z 24.09.2015, s. 9.

20 Kodeks najlepszych praktyk dotyczących przebiegu postępowania w zakresie kontroli pomocy państwa, Dz. Urz. UE C 253 z 19.07.2018, s. 14. 


\section{Dopuszczalność pomocy na wspieranie kultury i dziedzictwa kulturowego i zasady jej oceny}

Jak wskazano w powyższym punkcie, zasadniczo pomoc publiczna spełniająca łącznie przesłanki określone w art. 107 ust. 1 TFUE nie może być wprowadzona w życie, dlatego możliwość jej wprowadzenia w życie zależy od istnienia w traktatach wyjątku od zakazu wynikającego $\mathrm{z}$ art. 107 ust. 1 TFUE. W przypadku pomocy „kulturalnej” wyjątkiem tym jest art. 107 ust. 3 lit. d TFUE, zgodnie z którym „za zgodną z rynkiem wewnętrznym może zostać uznana pomoc przeznaczona na wspieranie kultury i zachowanie dziedzictwa kulturowego, o ile nie zmienia warunków wymiany handlowej i konkurencji w Unii w zakresie sprzecznym ze wspólnym interesem"21.

Ocena, w którym przypadku działanie państwa mieści się w ramach tego przepisu, jest dokonywana w oparciu o akty soft law zawierające szczegółowe wyjaśnienia KE dotyczące kryteriów, które będzie ona brała pod uwagę przy ocenie zgłoszonych środków. W zakresie pomocy „kulturalnej” KE wydała tylko jeden taki dokument Komunikat KE $w$ sprawie pomocy państwa przeznaczonej na filmy i inne utwory audiowizualne ${ }^{22}$. W przypadku zatem pomocy kulturalnej innej niż dotycząca filmów i utworów audiowizualnych ocena może być dokonana jedynie bezpośrednio w oparciu o art. 107 ust. 3 lit. d Traktatu. Zgodnie z przyjętymi zasadami ocena obejmuje w takim przypadku ustalenie, czy są łącznie spełnione przesłanki:

1) działanie państwa jest niezbędne do osiągnięcia celu,

2) działanie nie przekracza rozmiaru niezbędnego do realizacji celu,

3) działanie nie zmieni warunków wymiany handlowej i konkurencji w UE w zakresie sprzecznym ze wspólnym interesem.

Co do zasady, do działań w sferze kultury i dziedzictwa kulturowego stanowiących pomoc publiczną stosuje się ogólne zasady oceny, przedstawione w poprzednim punkcie. Środki te podlegają zatem obowiązkowi zgłoszenia KE, jednak rygory

21 Nie jest wykluczone zaistnienie innego wyjątku, np. w postaci art. 106 ust. 2 TFUE czy art. 107 ust. 3 lit. b TFUE. Są to jednak przypadki o innym charakterze, gdzie uzasadnieniem dopuszczalności nie jest rodzaj działalności (kultura, dziedzictwo kulturowe), ale inne względy (np. wykonywanie usługi w ogólnym interesie gospodarczym, spełnienie kryteriów uzasadniające objęcie innym rodzajem pomocy itp.). T. Skoczny wskazuje, że art. 107 ust. 3d TFUE ustanowiono w celu ochrony europejskiego przemysłu filmowego przed konkurencją amerykańską. T. Skoczny, Zakaz antykonkurencyjnej pomocy państwa, w: Prawo Unii Europejskiej. Zagadnienia systemowe, prawo materialne i polityki, omówienie wybranych orzeczeń ETS, Traktat o Unii Europejskiej, Traktat ustanawiający Wspólnotę Europejską, red. J. Barcz, Warszawa 2004, s. 787.

22 Komunikat KE w sprawie pomocy państwa przeznaczonej na filmy i inne utwory audiowizualne, Dz. Urz. UE C 332 z 15.11.2013, s. 1. 
związane z postępowaniem notyfikacyjnym są łagodzone objęciem tych środków procedurą uproszczoną, a także możliwością zwolnienia $\mathrm{z}$ obowiązku zgłoszenia w przypadku, gdyby stanowiły pomoc de minimis lub mieściły się w ramach wyłączeń grupowych. W tym ostatnim przypadku warto zauważyć, że aktualne rozporządzenie w sprawie wyłączeń grupowych obejmuje również pomoc na wspieranie kultury i dziedzictwa kulturowego (art. 53) przyznawaną na zasadach określonych $\mathrm{w}$ tymże rozporządzeniu.

\section{Problem stosowania przepisów o pomocy publicznej do finansowania niektórych zadań z zakresu kultury i dziedzictwa kulturowego}

Problematyczne w finansowaniu kultury i dziedzictwa kulturowego przez państwo jest to, czy działanie takie jest skierowane do przedsiębiorstwa. Innymi słowy, czy podmiot otrzymujący środki publiczne prowadzi działalność gospodarczą w rozumieniu prawa UE o pomocy publicznej ${ }^{23}$.

W sferze kultury i dziedzictwa kulturowego działalność prowadzą przede wszystkim publiczne (państwowe i samorządowe) instytucje kultury. Jednak można odnaleźć też inne podmioty, np. zarządzające zabytkowymi obiektami (np. spółki Skarbu Państwa i przedsiębiorstwa zarządzające kopalniami Wieliczka i Bochnia). Widoczna jest też pewna ewolucja polegająca na tym, że działania, takie jak prowadzenie muzeów, coraz częściej podejmowane są przez osoby prywatne. Udostępniają one prywatne zbiory czy kolekcje, a niekiedy zabytkowe obiekty (np. kopalnie, dworki, w których urządzono muzea) zwiedzającym. Publiczne instytucje nie są zatem obecnie jedynymi podmiotami zapewniającymi dostęp do dóbr kultury. W niektórych przypadkach mogą wręcz odczuwać konkurencję ze strony inicjatyw prywatnych. W tej sytuacji pojawia się w sektorze kultury i dziedzictwa kulturowego rynek - czyli w rozumieniu KE sytuacja, w której dany podmiot oferuje jakąś usługę lub towar potencjalnym nabywcom $\mathrm{w}$ warunkach konkurencji z innymi podmiotami. To zaś sprawia, że beneficjent wsparcia ze środków publicznych jest przedsiębiorstwem i podlega przepisom o pomocy publicznej, nawet jeśli na gruncie przepisów krajowych jest instytucją publiczną niedziałającą w celu osiągnięcia zysku.

Wytyczenie granicy między tym, co stanowi działalność gospodarczą, a tym, co jest zadaniem publicznym, przysparza trudności. Potwierdza to fakt, że w różnych

23 O. Simeon, P. Staviczky, M. Könings, M. Haralampopoulou, A. Jakob, C. Pettigs, State Aid for culture: best practices..., s. 3 . 
krajach członkowskich właściwe władze różnorodnie oceniały, jaki jest charakter działań wspierających sektor kultury i dziedzictwa kulturowego. Niektóre kraje (np. Holandia) uznawały, że 95\% środków w sferze kultury nie stanowi pomocy publicznej i ich nie zgłaszały KE, inne (np. Węgry) zgłaszały KE większość środków $^{24}$. Z pewnością niektóre środki były zgłaszane „na wszelki wypadek” w celu uzyskania pewności prawnej. W okresie, w którym pomoc publiczna na wspieranie kultury i dziedzictwa kulturowego nie była objęta wyłączeniami grupowymi, wymóg zgłaszania środków KE i oczekiwania na jej decyzję stanowił niewątpliwie niedogodność w realizacji przez państwa zadań publicznych z zakresu kultury. Z kolei ich niezgłoszenie mogło narazić państwo na zarzut bezprawnego przyznania pomocy publicznej - przy czym ocena, czy w ogóle była to pomoc, zostałaby dokonana dopiero w postępowaniu przed KE.

W sprawach poddanych w tym okresie ocenie przyjmowała ona zazwyczaj stanowisko, że działalność polegająca na finansowaniu przedsięwzięć kulturalnych ze środków publicznych nie stanowi pomocy publicznej lub też - nawet, jeśli stanowi - pomoc ta jest niewątpliwie zgodna $\mathrm{z}$ rynkiem wewnętrznym. Alternatywne sformułowanie świadczyło, że charakter prawny działalności kulturalnej pozostawał niekiedy niejasny również dla samej KE. Ciekawym elementem były również uzasadnienia decyzji. KE badała w nich zarówno charakter działalności beneficjenta, jak również spełnienie przesłanek z art. 107 ust. 1 TFUE, np. to, czy muzeum miało zasięg oddziaływania lokalny czy większy oraz czy istniała możliwość, aby przyciągało turystów z innych krajów członkowskich ${ }^{25}$. Potwierdzało to, że w sektorze kultury i dziedzictwa kulturowego stosuje się ogólne kryteria oceny charakterystyczne dla przedsiębiorstw, takie jak istnienie „rynku” usług kulturalnych czy transgraniczny zasięg działalności instytucji kulturalnej ${ }^{26}$.

Zatem zgodnie z ogólnymi zasadami pomocy publicznej nie jest istotne to, że np. art. 3 ust. 2 ustawy o organizowaniu i prowadzeniu działalności kulturalnej przewiduje, iż działalność ta nie stanowi działalności gospodarczej w rozumieniu odrębnych przepisów polskiego prawa. Podobnie np. art. 1 ustawy o muzeach, definiujący muzeum jako jednostkę organizacyjną nienastawioną na osiąganie zysku²7.

\footnotetext{
24 Tamże, s. 8 i nast.

25 Sprawa Pomoc państwa nr SA.36581 (2013/NN) - Grecja (Budowa Muzeum Archeologicznego w Mesarze, Kreta); Sprawa Pomoc państwa nr NN 136/A/02 - Francja (Środki dotyczące l’Ecomusée w Alzacji).

26 Zob. R. Ianus, M.F. Orzan, Aid Subject to a Discretionary Assessment under Article 107(3) TFEU, w: H.C.H. Hofmann, C. Micheau, State Aid Law of the European Union, Oxford 2016, s. 300-303, 307.

27 Krajowe przepisy dopuszczają prowadzenie działalności gospodarczej jako działalności dodatkowej przez muzea na zasadach określonych w art. 9 ustawy o muzeach.
} 
Ciekawym przypadkiem była niewątpliwie sprawa dotacji na remonty zabytkowych kopalń w Polsce: Guido i Królowa Luiza ${ }^{28}$. Beneficjentem dotacji celowej było Muzeum Górnictwa Węglowego w Zabrzu (samorządowa instytucja kultury), mające przeprowadzić remont obiektu, którym się opiekowało - zabytkowej kopalni. Sprawa została zgłoszona przez polskie władze KE, która uznała, że beneficjent jest przedsiębiorstwem $w$ rozumieniu prawa pomocy publicznej. Za taką oceną przemawiało to, że obiekt zabytkowy był wykorzystywany komercyjnie, czyli udostępniony odpłatnie zwiedzającym. Była też prowadzona dodatkowa działalność uboczna, jak sprzedaż pamiątek. Zbadano zatem przesłanki pomocowe, m.in. czy zabytkowa kopalnia położona w Polsce mogłaby przyciągać turystów z innych krajów członkowskich. W tym kontekście KE zauważyła, że w innych państwach członkowskich również są tego rodzaju atrakcje turystyczne, więc nie można wykluczyć, że działalność polskich kopalń wywiera wpływ na rynek wewnętrzny UE. Po ustaleniu, że dotacja na remonty zabytkowej kopalni stanowi pomoc publiczną, KE zbadała ją w świetle art. 107 ust. 3 lit. d, uznając, że pomoc ta jest zgodna $\mathrm{z}$ rynkiem wewnętrznym. Ocena ta była zatem korzystna dla państwa polskiego.

$\mathrm{Na}$ tle tej sprawy można jednak postawić pytanie, czy działanie polegające na przyznaniu dotacji na remont zabytkowego obiektu powinno być w ogóle rozpatrywane w kategoriach pomocy publicznej. Mimo tego, że zabytkowe obiekty są udostępniane odpłatnie i można dopatrzyć się rynku obejmującego różne kraje członkowskie w tym sektorze, nadal kopalnie te są obiektami dziedzictwa kulturowego i obowiązkiem państwa jest ich zachowanie dla przyszłych pokoleń. Czy ewentualna ocena KE powinna być przeszkodą do ratowania tego rodzaju obiektów? Zauważyć należy, że ocena dokonywana na podstawie art. 107 ust. 3 lit. d TFUE w przypadku polskich kopalń sprowadzała się do sprawdzenia, czy działanie (przekazanie dotacji) było niezbędne dla osiągnięcia celu, czy była ona adekwatnym środkiem oraz czy jej wysokość nie wykraczała ponad to, co niezbędne dla osiągnięcia celu. Skoro te przesłanki były spełnione, KE wydała decyzję o niewnoszeniu zastrzeżeń do takiego środka. Ocena miała zatem charakter formalny. KE nie badała, czy można sfinansować ze środków publicznych remont zabytkowego obiektu, ale czy państwo polskie nie wykroczyło ponad to, co jest niezbędne do przeprowadzenia tego remontu. Można się zastanawiać, czy w ogóle wchodziłaby w grę ewentualna negatywna ocena KE dla tego rodzaju przedsięwzięcia? Jeśli tak, to interesujące byłyby jej skutki. W przypadku gdyby dotacja nie została jeszcze przekazana beneficjentowi, nie można byłoby jej przekazać, co zagrażałoby

Sprawy Pomoc państwa: nr SA.38122 (2014/N) - Polska (Pomoc na zachowanie dziedzictwa kulturowego w kopalniach węgla kamiennego „Guido” i „Królowa Luiza”). 
zabytkowemu obiektowi. Z pewnością nie byłoby to celem prawa UE. W sytuacji natomiast, gdyby dotacja została już przekazana - zasadniczo powinna zostać przez niego zwrócona państwu ${ }^{29}$. O ile jednak podmiot prywatny ponosi ekonomiczne konsekwencje otrzymania pomocy podlegającej zwrotowi, to o takowych trudno mówić, gdy chodzi o podmioty publiczne, zwłaszcza publiczną instytucję kultury. W jej przypadku ewentualny zwrot pomocy może nie być możliwy, jeśli środki już zostały wydane. Co można zrobić w takiej sytuacji? Nawet zlikwidowanie takiej „niewypłacalnej” instytucji nie rozwiązuje sprawy, bo przecież nadal trzeba opiekować się zabytkowym obiektem, więc należałoby powołać do życia kolejną instytucję kultury w tym celu. Trudno zatem dostrzec sens i cel oceniania tego rodzaju przypadków, tak, jak można by oceniać działalność podmiotu prywatnego.

W wydanym w 2016 r. dokumencie Zawiadomienie w sprawie pojęcia pomocy państwa w rozumieniu art. 107 ust. 1 Traktatu o funkcjonowaniu Unii Europejskiej KE przedstawiła stanowisko w kwestii oceny środków z dziedziny kultury i dziedzictwa kulturowego.

W punkcie 34 Zawiadomienia KE wyjaśniła, że niektóre działania związane z kulturą, zachowaniem dziedzictwa kulturowego i ochroną przyrody mogą być organizowane w sposób niekomercyjny i nie mieć charakteru gospodarczego. Ich finansowanie ze środków publicznych nie musi więc stanowić pomocy państwa. Jako przesłankę odróżniającą charakter gospodarczy od niegospodarczego KE wskazała m.in. odpłatność dostępu do dóbr kultury i dziedzictwa kulturowego. „Finansowanie publiczne kultury lub działań służących zachowaniu dziedzictwa kulturowego, których wyniki są dostępne dla ogółu społeczeństwa nieodpłatnie, spełnia czysto społeczny i kulturowy cel o charakterze niegospodarczym. Fakt, że odwiedzający instytucje kultury lub uczestnicy wydarzeń kulturalnych lub działań służących zachowaniu dziedzictwa kulturowego, w tym ochronie przyrody, otwartych dla ogółu społeczeństwa są zobowiązani do wniesienia świadczenia pieniężnego, które pokrywa jedynie ułamek kosztów rzeczywistych, nie zmienia niegospodarczego charakteru tej działalności, ponieważ takiego świadczenia nie można uznać za rzeczywiste wynagrodzenie za świadczoną usługę".

Natomiast wydarzenia kulturalne finansowane głównie z opłat wnoszonych przez odwiedzających lub użytkowników lub w inny komercyjny sposób (np. wystawy komercyjne, kina, komercyjne spektakle muzyczne i festiwale, szkoły artystyczne finansowane głównie z czesnego) należy uznać za mające charakter gospodarczy.

29 Zwrot niezgodnej z rynkiem pomocy jest konieczny dla przywrócenia stanu zgodnego z prawem. Zob. Komunikat KE Zawiadomienie Komisji w sprawie odzyskiwania pomocy państwa niezgodnej z prawem i z rynkiem wewnętrznym, Dz. Urz. UE C 247 z 23.07.2019, s. 1. 
Podobnie wydarzenia kulturalne lub działania służące zachowaniu dziedzictwa kulturowego przynoszące korzyści wyłącznie niektórym przedsiębiorstwom, a nie ogółowi społeczeństwa (np. renowacja zabytkowego budynku wykorzystywanego przez przedsiębiorstwo prywatne) należy zasadniczo uznać za działalność gospodarczą (punkt 35 Zawiadomienia).

Powyższe wyjaśnienie ma istotne znaczenie. Interpretacja pojęcia „działalność gospodarcza" w przypadku pomocy na wspieranie kultury i zachowanie dziedzictwa kulturowego została bowiem zawężona: przesłanka oferowania dóbr bądź usług na rynku została zastąpiona przesłanką odpłatności/komercyjności działalności. W świetle wyjaśnień, działalność niekomercyjna jest to działalność nieodpłatna albo działalność odpłatna, w której świadczenia wnoszonego przez zainteresowanych nie można uznać za rzeczywiste wynagrodzenie za świadczoną usługę. Wydaje się zatem, że „komercyjność” nawiązuje do ceny za usługę wyznaczanej przez rynek, kalkulowanej z uwzględnieniem kosztów i odpowiedniego zysku, poddanej prawom ekonomii.

Za nieobjęte przepisami o pomocy publicznej zostało także uznane finansowanie budowy infrastruktury kulturalnej na zasadach określonych w „siatce analitycznej” KE dotyczącej kultury, będącej dokumentem uzupełniającym Zawiadomienie ${ }^{30}$.

W kwestii wpływu na wymianę handlową między państwami członkowskimi, zgodnie z punktem 197 lit. b Zawiadomienia, niektóre rodzaje działalności kulturalnej mogą nie wywierać wpływu na wymianę handlową między państwami członkowskimi z uwagi na lokalny charakter. Dotyczy to wydarzeń kulturalnych i podmiotów prowadzących działalność gospodarczą, w przypadku których istnieje jednak niewielkie prawdopodobieństwo przyciągnięcia użytkowników lub gości ze szkodą dla podobnych ofert w innych państwach członkowskich. Tylko finansowanie przyznane dużym i uznanym instytucjom kultury oraz na duże i renomowane wydarzenia kulturalne w państwie członkowskim, które są szeroko promowane poza regionem macierzystym, mogą mieć wpływ na wymianę handlową między państwami członkowskimi. Nastąpiła zatem istotna zmiana w ustalaniu istnienia tego kryterium na gruncie „kulturalnym”. W miejsce domniemania jego istnienia ${ }^{31}$ wprowadzono wyjątek w postaci „lokalnego” oddziaływania obiektu lub przedsięwzięcia.

30 Infrastructure analytical grid for culture, heritage and nature conservation, https://ec.europa.eu/competition/state_aid/modernisation/grid_culture_en.pdf [dostęp: 5.11 .2020 r.].

31 Zob. P. Marquardt, Pomoc publiczna dla matych i średnich przedsiębiorców, Warszawa 2007, s. 52. 


\section{Zakończenie}

Przepisy o pomocy publicznej stosuje się do publicznych interwencji w działalność gospodarczą. Z uwagi na szeroką interpretację tego ostatniego pojęcia znajdują one zastosowanie również do działań, które nie stanowią działalności gospodarczej w świetle prawa krajowego ${ }^{32}$. Publiczna działalność w zakresie kultury i zachowania dziedzictwa kulturowego stanowi niewątpliwie specyficzną niszę, w której niekiedy te przepisy znajdują zastosowanie. Wiąże się to z charakterem tej działalności, w której stykają się dwa odmienne cele - umożliwienie społeczeństwu obcowania z kulturą i dziedzictwem kulturowym oraz cel gospodarczy, który w przypadku działalności instytucji publicznych ma charakter drugoplanowy.

Dylematy związane $\mathrm{z}$ oceną środków w sferze kultury i dziedzictwa kulturowego są elementem szerszych przemian, jakie przechodzi prawo pomocy publicznej. Treść przepisów TFUE nie zmieniła się od początków istnienia Wspólnot Europejskich. Jednak cele reglamentacji pomocy nie wydają się takie same jak kilkadziesiąt lat temu. Wówczas chodziło o zapobieżenie rywalizacji w dotowaniu przedsiębiorstw między państwami członkowskimi. Z czasem cele pomocy uległy rozszerzeniu i zmianom ${ }^{33}$. Wychodząc naprzeciw nowym wyzwaniom, KE przeprowadziła reformę - modernizację pomocy publicznej. Nowe podejście znalazło wyraz w Zawiadomieniu, jego elementem były też ułatwienia proceduralne we wdrażaniu pomocy ${ }^{34}$. Dokument ten wyjaśnił nowe podejście KE w sprawach bu-

32 O tym, jak szerokie spektrum działań wchodzi w zakres pomocy publicznej na wspieranie kultury i zachowanie dziedzictwa kulturowego, mogą świadczyć podane przykłady. Przedmiotem decyzji KE były m.in. wspieranie działalności wydawniczej w języku baskijskim w Hiszpanii [Sprawa Pomoc państwa nr SA.47448 - Hiszpania (Promowanie języka baskijskiego w cyfrowych mediach informacyjnych)], wspieranie tańca, muzyki i poezji [Sprawa Pomoc państwa nr 2144 (N 2011) - Hiszpania (Pomoc państwa na rzecz tańca, muzyki i poezji)], pomoc dla teatrów i cyrków [Sprawa Pomoc państwa nr SA.32119 - Hiszpania (Pomoc państwa na działalność teatralną I cyrkową)], tworzenie funduszy wspierających produkcję filmową [Sprawa Pomoc państwa nr SA.32836 (2011/N) - Słowacja (Fundusz Audiowizualny)], zachęty podatkowe dla producentów gier wideo zawierających aspekty kulturowe [Sprawa Pomoc państwa nr SA.36139 (2013/C) (ex 2013/N) dotycząca planu Zjednoczonego Królestwa przyznania pomocy na rzecz gier video)], remonty zabytkowych obiektów, finansowanie działalności muzeów [Sprawa Pomoc państwa nr N 630/2003 - Italia (Musei di interesse locale - Regione autonoma della Sardegna)], a nawet budowa stadionów wykorzystywanych $\mathrm{m}$.in. do organizacji wydarzeń kulturalnych [Sprawa Pomoc państwa nr SA 35501 (2013/N) - France Financement de la construction et de la rénovation des stades pour l'EURO 2016, zob. również sprawę Pomoc państwa nr SA.47683 (2017/N)-Finland (Tampere Arena)].

33 Zob. P.L. Parcu, G.Monti, M. Botta, w: EU State Aid Law. Emerging trends at the National and EU Level, Cheltenham 2020, s. 1-5.

34 C. Micheau, Evolution of State Aid Rules: Conceptions, Challenges and outcomes, w: H.C.H. Hofmann, C. Micheau, State Aid Law of the European Union, Oxford 2016, s. 33-34. 
dzących wątpliwości, takich jak m.in. pomoc na wspieranie kultury i dziedzictwa kulturowego. Ułatwienia proceduralne objęły ten rodzaj pomocy wyłączeniami grupowymi lub uproszczoną procedurą oceny.

Słuszne jest ocenianie w świetle pomocy publicznej tych działań państwa, w których dochodzi do finansowania ze środków publicznych wydarzeń kulturalnych mających charakter komercyjny. Mimo że również te wydarzenia realizują cel kulturalny, to jednak odbywają się w ramach działalności gospodarczej podmiotów, których działanie jest podporządkowane prawom rynkowym. Jednak na drugim biegunie działalności kulturalnej są działania, takie jak zachowanie dziedzictwa kulturowego czy zapewnienie niezbędnej infrastruktury do prowadzenia niekomercyjnej działalności kulturalnej. Poddawanie ich ocenie pod kątem pomocy publicznej budzi wątpliwości. Nie jest to bowiem działalność gospodarcza. Nie jest również jasne, czemu taka ocena miałaby służyć.

$\mathrm{W}$ świetle powyższych dylematów pozytywnie należy ocenić aktualne stanowisko KE dotyczące oceny środków wspierających kulturę i zachowanie dziedzictwa kulturowego. Mimo pewnych wątpliwości czytelnie identyfikuje ono problem charakteru działalności kulturalnej i proponuje kryteria oceny pozwalające ograniczyć kontrolę do przypadków, w których jest ona uzasadniona. Jednak nie usunięto całkowicie wątpliwości. Przesłanki „komercyjności” albo „lokalnego charakteru” działania beneficjenta nadal mogą być różnie rozumiane przez państwo członkowskie i KE. Nie jest również jasne, jak ustalić, czy obiekt zabytkowy w jednym państwie członkowskim oddziałuje na frekwencję turystyczną w podobnych obiektach w innym państwie członkowskim, przez co mogłyby one ponieść „szkodę” (zob. Zawiadomienie, pkt. 197 lit. b) ${ }^{35}$.

Wydaje się, że poza wyjaśnieniami przyjętymi w Zawiadomieniu dużą rolę odgrywa objęcie działań w sferze kultury i dziedzictwa kulturowego wyłączeniami grupowymi oraz - w przypadku gdyby podlegały one ocenie KE - uproszczoną procedurą notyfikacyjną. Niewątpliwie ułatwia to realizację przez państwa członkowskie tych zadań publicznych, uwalniając większość przypadków od obowiązku zgłoszenia $\mathrm{KE}^{36}$.

35 Warto zauważyć, że we wcześniejszych sprawach będących przedmiotem decyzji KE nie przedstawiała ona racjonalnych przesłanek, na podstawie których uznawała, że wpływu na wymianę handlową między państwami członkowskimi nie było. Zob. P. Nicolaides, Why Can the Commission not be consistent...

36 Wskazuje się, że ok. 95\% przypadków udzielanej pomocy jest obecnie objęte wyłączeniami grupowymi i nie jest oceniane przez KE, która skupia się na najpoważniejszych przypadkach. J.L. Buendìa Sierra, A Brave New World in State Aid?, European State Aid Law Quarterly 2019, t. 18, nr 4, s. 443. 


\section{Bibliografia}

Buendìa Sierra J.L., A Brave New World in State Aid?, European State Aid Law Quarterly 2019, t. 18 , nr 4.

Marquardt P., Pomoc publiczna dla małych i średnich przedsiębiorców, Warszawa 2007.

Micheau C., Evolution of State Aid Rules: Conceptions, Challenges and outcomes, w:H.C.H.Hofmann, C. Micheau, State Aid Law of the European Union, Oxford 2016.

Nicolaides P., Why Can the Commission not be consistent in its analysis of economic activity and affectation of trade?, http://stateaidhub.eu/blogs/stateaiduncovered/post/1665 [dostęp: 5.11.2020 r.].

Parcu P.L., Monti G., Botta M., w: EU State Aid Law. Emerging trends at the National and EU Level, Cheltenham 2020.

Postuła I., Werner A., Prawo pomocy publicznej, Warszawa 2008.

Psychogiopoulou E., State Aids to the Publishing Industry and Cultural Policies in Europe, European State Aid Law Quarterly 2013, t. 12, nr 1.

Simeon O., Staviczky P., Könings M., Haralampopoulou M., Jakob A., Pettigs C., State Aid for culture: best practices at regional and local level, http://www.issirfa.cnr.it/andrea-ciaffi-ececilia-odone-a-cura-di-le-politiche-europee-per-le-regioni-dalle-policies-alla-regulationdicembre-2016.html [dostęp: 5.11.2020 r.].

Skoczny T., Zakaz antykonkurencyjnej pomocy państwa, w: Prawo Unii Europejskiej. Zagadnienia systemowe, prawo materialne i polityki, omówienie wybranych orzeczeń ETS, Traktat o Unii Europejskiej, Traktat ustanawiający Wspólnotę Europejską, red. J. Barcz, Warszawa 2004.

Stoczkiewicz M., Pomoc państwa dla przedsiębiorstw energetycznych w prawie Unii Europejskiej, Warszawa 2011. 
